DOI: 10.21005/pif.2021.47.E-01

\title{
CULTURAL LANDSCAPE AND TYPOLOGY OF THE KHARANAQ VILLAGE IN IRAN
}

\section{Mojgan Aghaeimeybodi}

Master of Iranian Architectural Studies

Author's Orcid number: 0000-0002-9442-3025

\section{Elham Andaroodi}

Faculty Member, Associate Professor

Author's Orcid number: 0000-0002-0790-6230

Department of Architecture

University of Tehran, Tehran, Iran

\section{ABSTRACT}

This article intends to analyse the historic village-castle of Kharanaq, which has been inhabited for over a thousand years in various historical periods. Different layers of habitation make Kharanaq's residential context different from other castles or villages of Iran. This village-castle is fortified by high walls and is located at the edge of the Central Desert of Iran. This article focuses on identifying the interaction of the inhabitants with the desert environment of the village-castle through an analysis of its cultural landscape and the typology of its residential houses, as well as the current situation of its architecture and spaces.

Key words: Kharanaq, village-castle, cultural landscape, spatial organization. 


\section{INTRODUCTION}

Kharanaq village is located about $79 \mathrm{~km}$. northeast of Yazd city, in a mountainous area at the edge of the desert with hot and dry climate, along an important pilgrimage road connecting Yazd to the city of Mashhad. The primary core of this village-castle rarely has no separate governmental facilities and structures. The body of the castle which was constructed around a central core based on a coherent plan has been occupied by people for over 1,000 years. According to historical texts, this village was built in pre-Islamic periods and was first inhabited by Zoroastrians (Shahzadi,1995, 15). The existence of Chak Chak fire temple, which is one of the most famous Zoroastrian temples of Iran near Kharanaq is the evidence for this claim. The archaeological researches and findings have also proved the Sassanid foundations of Kharanaq village-castle between $2^{\text {nd }}$ to $6^{\text {th }}$ centuries $A D$. However, various visible parts of the Castle date back to $14^{\text {th }}$ and $15^{\text {th }}$ centuries $A D$, although constructions and changes in the Castle's architecture had continued up to 50 years ago when it was still inhabited by the locals (Amiri, 2005, 2). Its prevailing architecture dates back to $10^{\text {th }}$ and $11^{\text {th }}$ centuries, which is often the Seljuk style, even though we can also see pre-Islamic architectural features like soft elliptical arches in the village-castle.

\section{METHODOLOGY}

The present article focuses on identifying the interaction of the inhabitants with the environment of the Kharanaq village-castle as a case study research, through an analysis of its cultural landscape and the typology of its residential houses, as well as the current situation of its architecture and spaces. This research was conducted with an interpretive historical method and relies on analysis of library resources such as historical documents and archival resources of the Ministry of Cultural Heritage, Tourism and Handicrafts of Iran, and the authors field surveys and studies such as documentation of the Kharanaq village-castle through map preparation and photography.

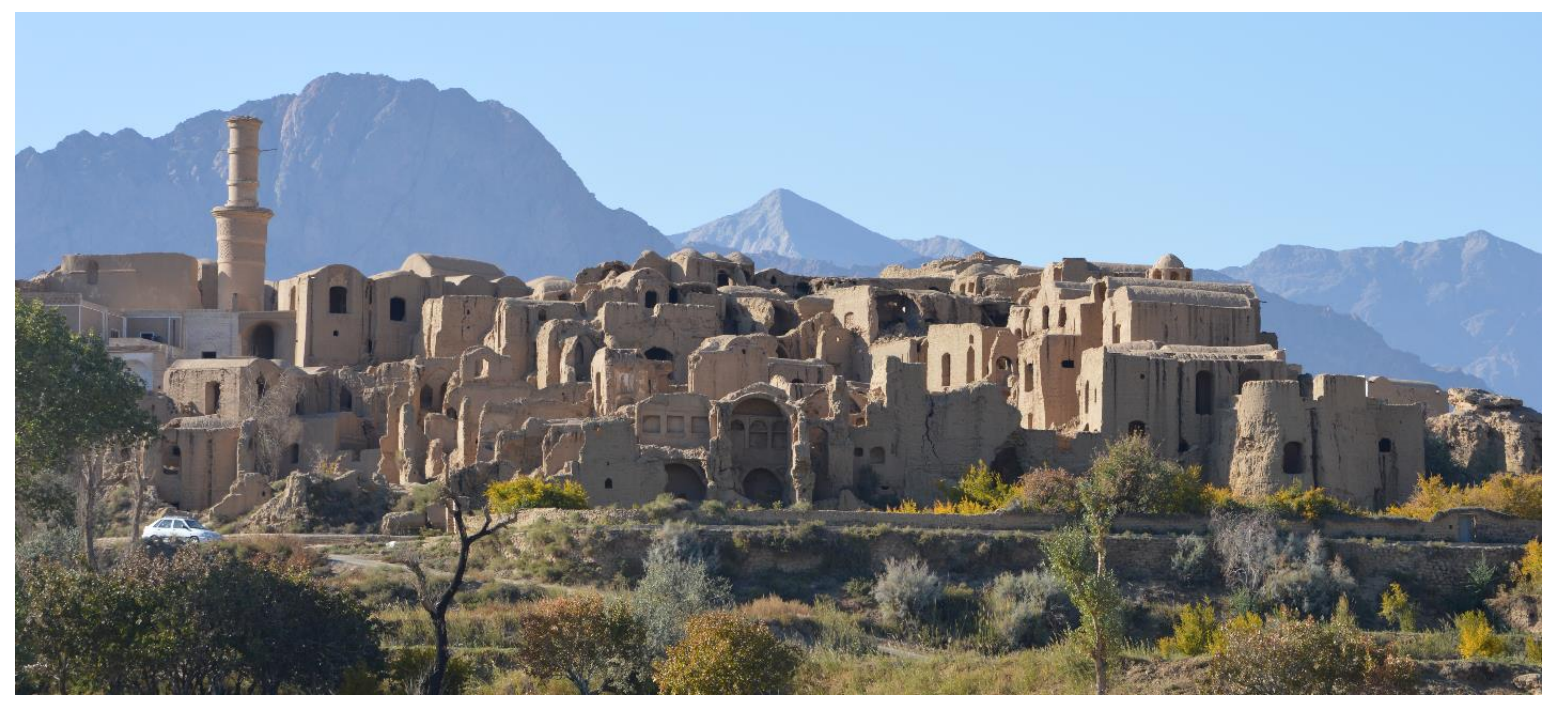

Fig. 1. The Panoramic view of the Kharanaq Village-Castle over a hill, and the fields on foot of it. Source: fot. authors

\section{CULTURAL LANDSCAPE OF KHARANAQ VILLAGE-CASTLE}

The location and the architecture of Kharanaq village-castle demonstrate the evidence of vernacular and historical cultural landscape. The castle is located at the border of a small mountainous area at the edge of desert. Kharanaq village which ends to a desert on its south side, is surrounded 
by the mountains and farms with a U-shape at the north. This mountainous area is important for the creation of a human settlement in a dry desert since it supports formation of a small river at the east of the village. The signs of interaction of Kharanaq's people with severe desert climate can be readable in the following features:

- The mudbrick construction of the buildings with compact adjacencies and central courtyards as small gardens inside larger houses

- The organic organization of the residential tissue with narrow, half-covered meandrous passageways which reduce the severe sunlight in the alleys (Fig. 2, 3)

- The location of the Castle with its residential houses beside the hillside farms and gardens with irregular land pattern, at the north of the castle

- The adjacency of the Castle and the farms with the river as an important water resource. The river runs along a mountainous area at the east side of the village

- The role of the Castle as a fortified and safe place as a reaction to dangers of enemy attack

- The importance of the Castle as a supporting stop for the south to north-east historical road

Here the paper discusses the above mentioned features in detail:

Placing alongside communication paths and at the same time, locating in the catchment area of the desert with water resources, made the village a significant place for merchants and caravans from pre-Islamic periods until recent times. A 17th-century caravanserai beside the castle proves its important location along Great Khorasan Road.

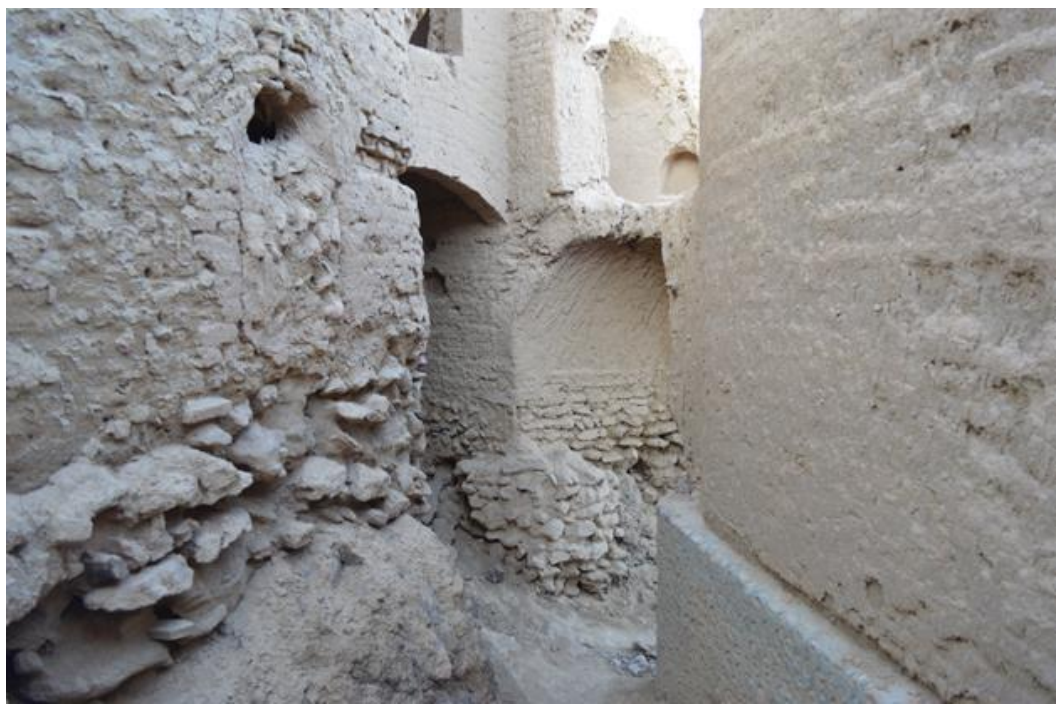

Fig. 2. Passageways of The Kharanaq village-castle. Source: fot. authors

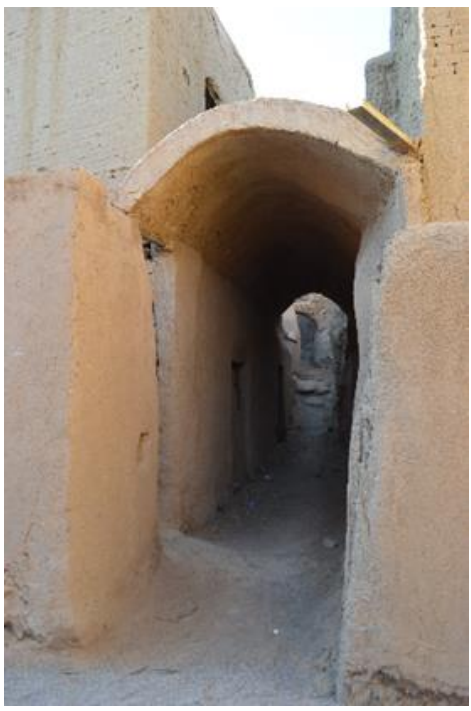

Although the Kharanaq region is a dry land on the outskirts of the Central Desert of Iran, and in modern times has faced severe water scarcity for economic activities (especially for agriculture), it is one of the places in Iran where water can be accessed through the digging of the Qanat (Arman \& Hanachi, 2014, 68). The river at the east of the village is a valuable water resource. One of the most significant factors influencing the formation of the village and the settlement of the population in this particular place is the existence of rich groundwater tables. 
This village-castle was built on a hill dominant to the area around, with a better defensive location. It was built like a fortification on a hill, with tall and interconnected defensive walls and six watchtowers (Amiri, 2005, 3). This historical village consists of a complicated labyrinth of streets, tunnels, and passageways with zig-zag and narrow dimensions that are mostly roofed with special strengthening coverings of traditional mud-brick architecture, including Arch and Tevyzeh and Sabat (covered passage). There are some reasons for this adaptation; the first reason is to maximize the size of castle's houses by reducing the dimension of passageways; for this purpose, the inhabitants have even made rooms on the passageways. The second reason is about regulating the environmental conditions of Kharanaq by narrow and roofed passageways, which reduce the heat exchange with the outside, especially in summer. In addition, it allows at least two floors of the building to always be in the shade which is very suitable for the hot and dry climate of Kharanaq (Arman \& Hanachi, 2014, 73). There are also some other important reasons for the composition of the village-castle, like the proximity of the houses and accordingly the inhabitants' social relations that have made the castle more secure due to better defending structures and human interactions to defeat the invaders. In addition, the composition of buildings and also the narrow and roofed passageways can play a more robust and static role in countering the thrust of the roofs.

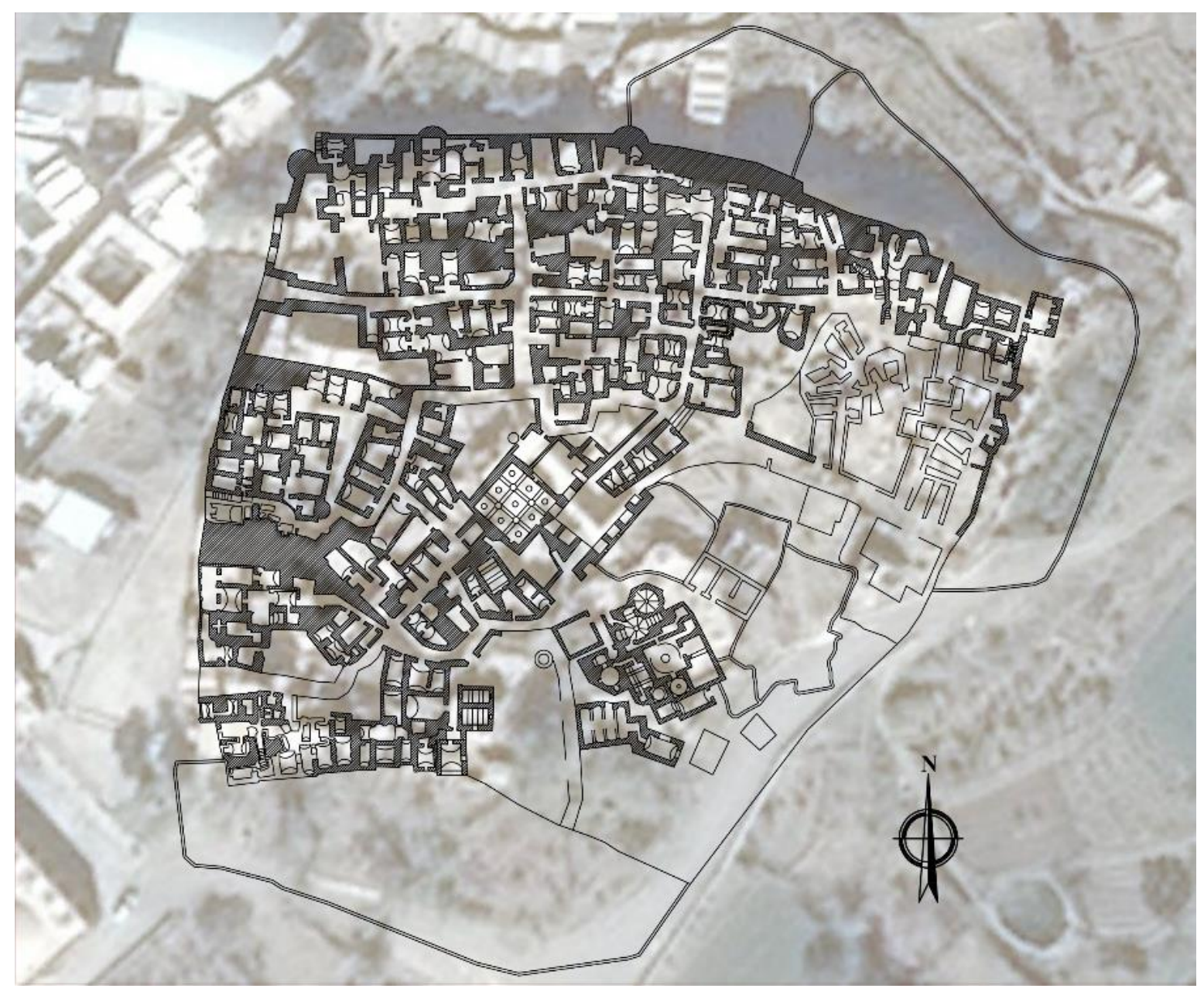

Fig. 3. Plan of Kharanaq village-castle matched with the aerial photos and plans of the castle's buildings. Sources: ICHHTO, and Arman \& Hanachi, 2014, 72; redraw by the authors 
Kharanaq village-castle, with the area of about 1.1 hectares, has public spaces and buildings for the local communications like a public bathhouse, a mill, Hussainiya, and a central mosque which was built by the castle dwellers many years ago and have been repaired and revitalized by them. All of these public spaces are located in the central part of the castle, with residential houses and passageways surrounding them.

The construction materials in this village-castle are mainly sun-dried mud bricks, making it one of the largest collections of adobe buildings in Iran, while some other materials such as stone, brick, and plaster are also used in its architecture.

For two reasons, this village-castle has observed factors of sustainability and sustainable interaction with the environment, first for the materials that had been used in its construction in the hot and dry climate of Yazd, and second due to its type of placement on the topography (on the hill). This successful adaptation to the environment serves the purpose of achieving maximum passive cooling, thermal comfort, and least energy consumption to the historical village-castle of Kharanaq.

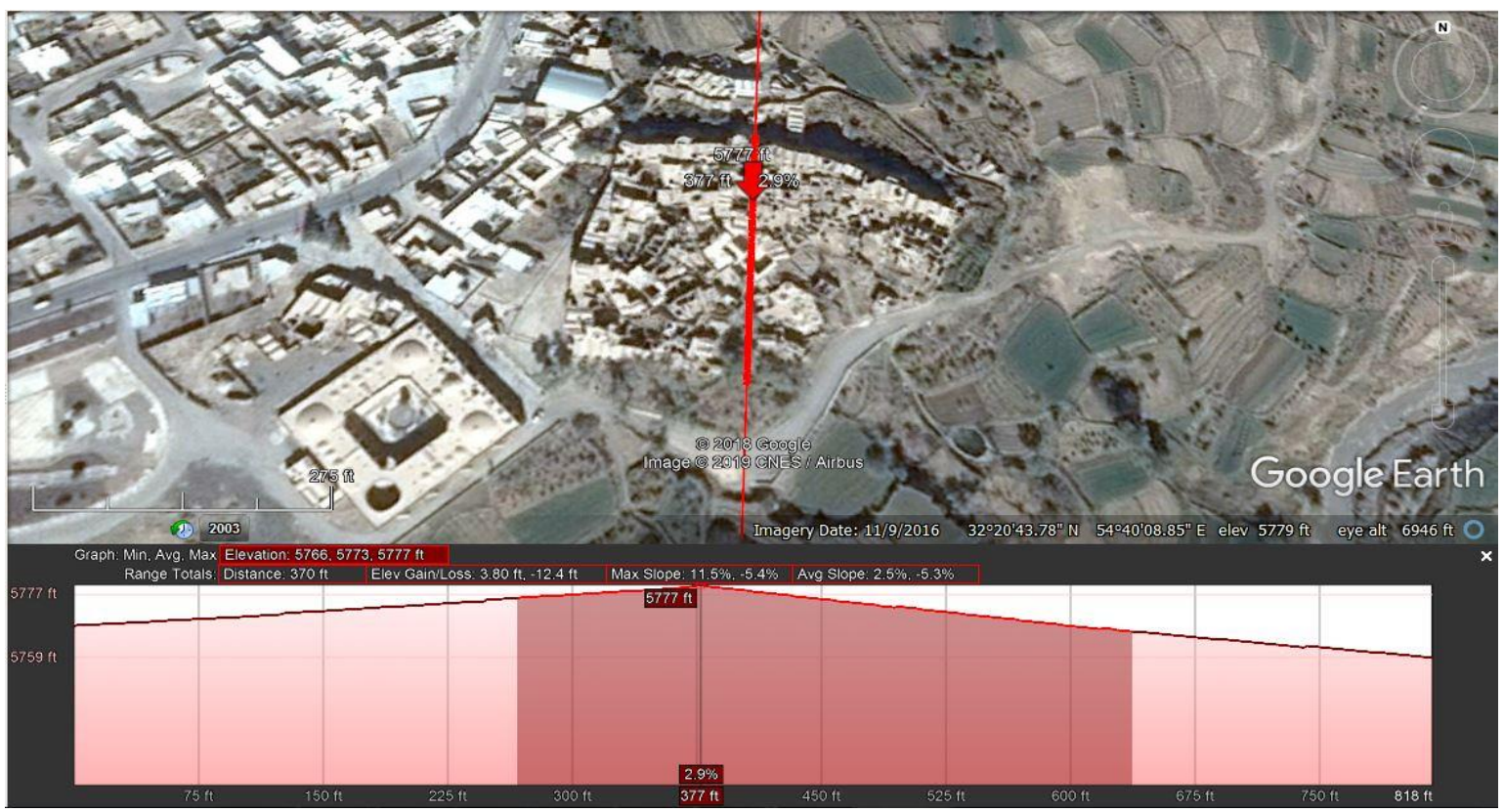

Fig. 4. North-South elevation of Kharanaq village-castle. Source: Google Earth

\section{PHYSICAL ANALYSIS OF THE KHARANAQ HOUSES}

This historical village has more than 80 houses; most of them were designed and built in two or three floors according to the economic and social status of the settlers. Lower floors of these houses were usually allocated to keeping livestock, and the upper floors were allocated to the dwelling. In the three-story houses, the middle floors were built to store forage and food. The lower floors of the houses, which sometimes have an equal level to the outer passageways, do not have any doors or windows directly to the outside of the castle in order to protect the village-castle from the intrusion of the bandits and invaders, therefore its connections are through passages within the castle and the main gateways.

The foundation of all homes (regardless of the economic status of their owners) is the rubble stone, which is brought from a distance in the base of the mountain to the village, and then adobe or mud walls were constructed on this foundation. The roofs, doors, and windows of the houses are all made of wood. 


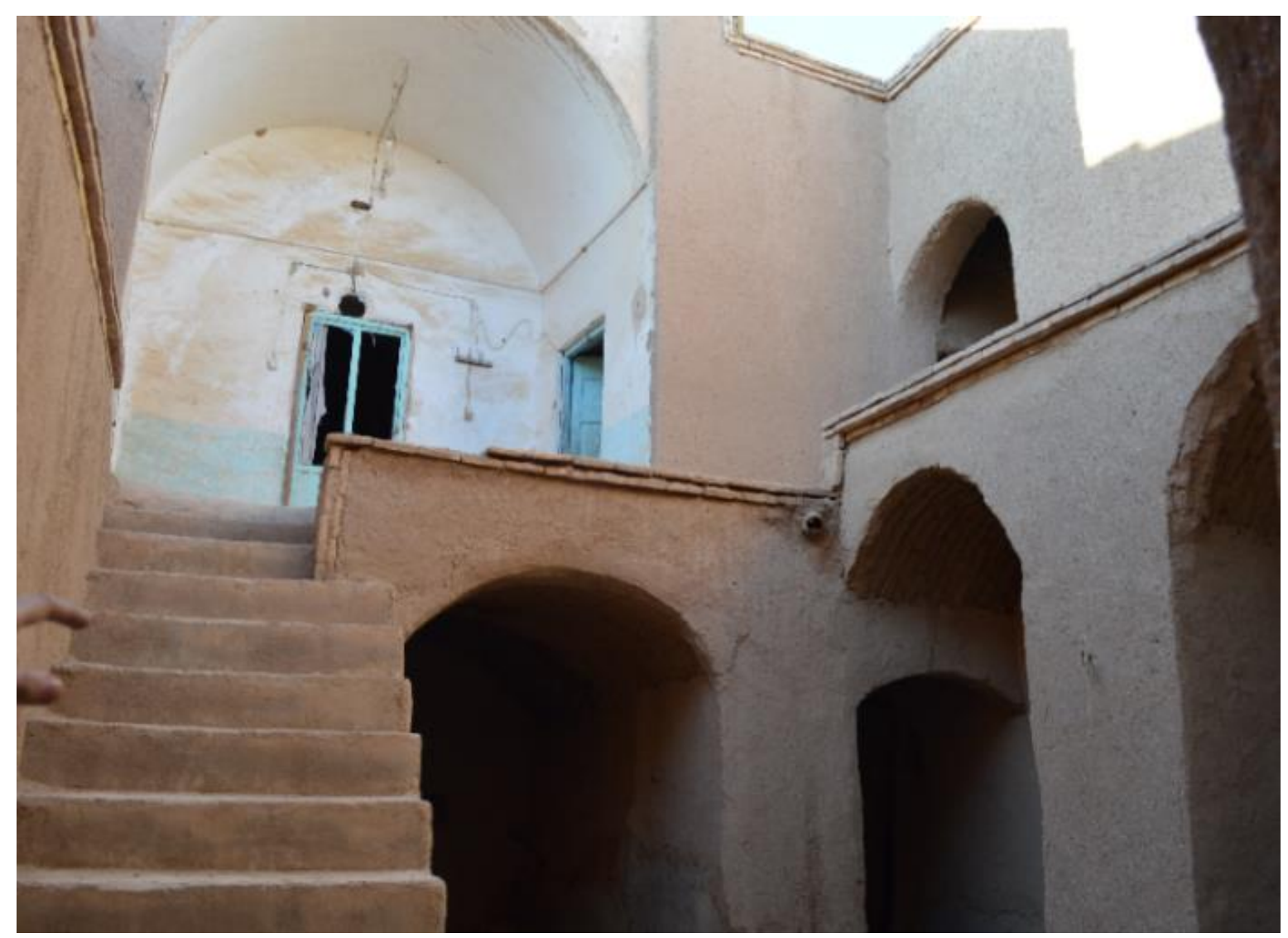

Fig. 5. Inside the yard of a house in the Kharanaq village-castle. Source: fot. authors
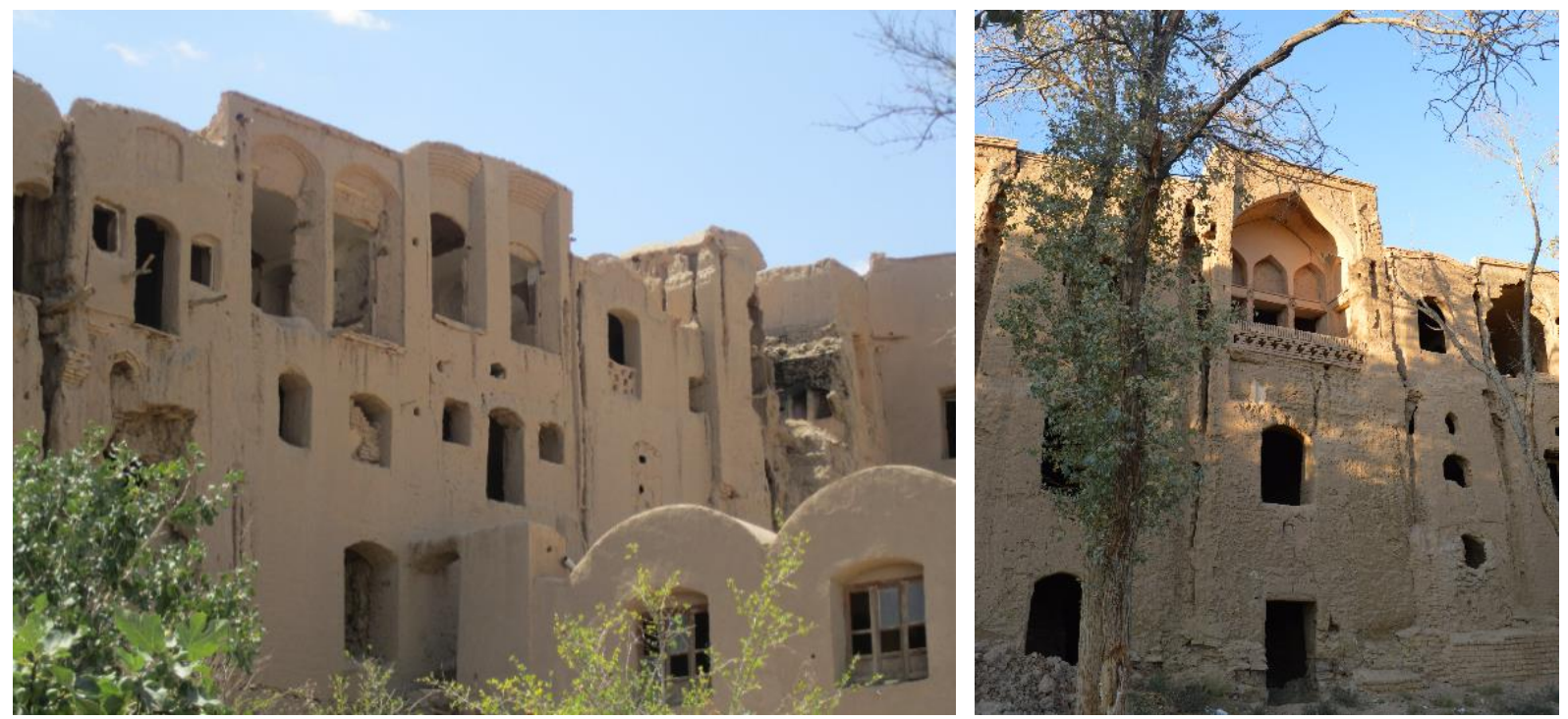

Fig. 6. view of three-floor houses of the Kharanaq village-castle. Source: fot. authors 
By examining the current status of the castle, it can be clearly seen that the rooms of the houses are not in a specific orientation and are formed depending on the direction of passageways in different orientations. The different arrangement of these rooms creates a unique living space in the village-castle. The spaces in a typical village-castle residential house includes rooms, a kitchen, a bathroom, a stable, and a workshop; however, the stable and the workshop are among the areas which are not found in all the castle houses, and also the kitchen is sometimes shared between some neighboring houses (Arman \& Hanachi, 2014, 76). What all of these houses have in common is the separation of the stable and bathrooms from the dwelling section, which is made possible by the creation of an intermediate space or by the difference in height.

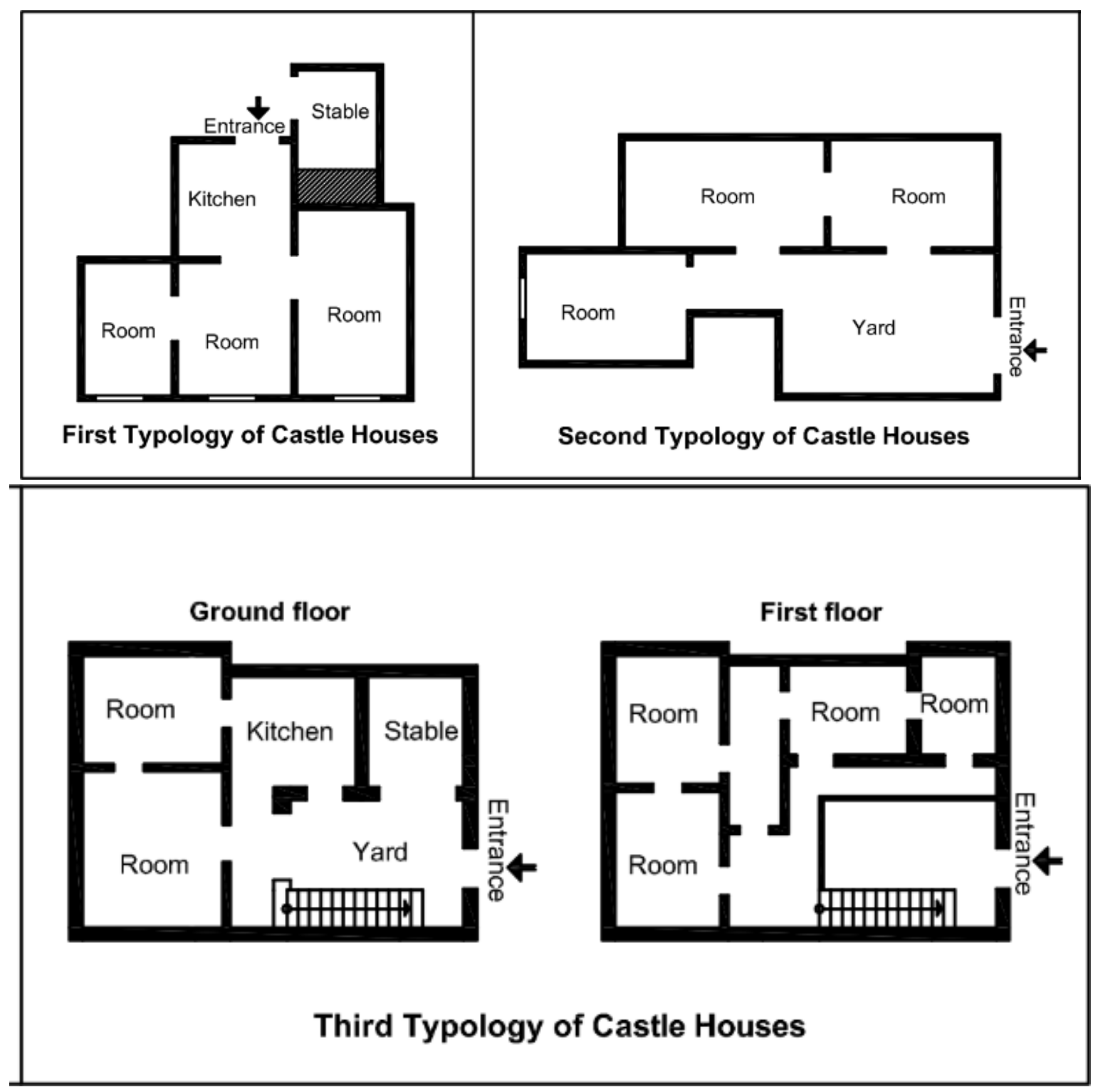

Fig. 7. Plan of three houses in Kharanaq village-castle representing the typology of the houses. Source: authors

There are three typologies of the village-castle's houses according to their spatial organization (Arman \& Hanachi, 2014, 76). The first typology is the spatial organization of the houses adjacent 
to passageways in one or two stories without a courtyard. This type of arrangement is the most common typology in the castle. Most of the castle's homes have small areas and simple components and do not have a courtyard. In contrast, there is another typology of the castle's houses in which different spaces of the house are located around a courtyard in one or two stories (Fig. 5), which is the second type. This spatial organization is similar to the traditional houses of Yazd with courtyards and is the rarest typology among castle's houses.

The third typology of village-castle's houses is the formation of spatial organization as a set of neighborhood units. These unique groups of houses, which are the most fascinating and varied residential spaces of the castle and distinguish Kharanaq village-castle from other organic textures, were formed in three floors and a limited number of them, in four floors (Fig. 6) (Arman \& Hanachi, 2014,77 ). Although it is difficult to determine the exact boundary of the houses in this typology, and now it seems impossible due to extensive demolition, it is somewhat possible to speculate on the composition of several houses that may have been related to each other. The houses of the castle were inhabited until the late 1960s and gradually were abandoned by the inhabitants.

\section{EXPANSION OF THE VILLAGE IN THE MODERN ERA}

About 100 years ago, with an increase to the population of Kharanaq, as well as the relative security of the region in the first Pahlavi era, and lack of modern facilities and spaces in the castle, some of the natives started to build bigger houses outside of the village-castle. These houses, which are the first stage of development in the village were built in single or double stories, and their rooms were located around or on one side of the central courtyard similar to the style of traditional and vernacular houses of Yazd with climatically stable materials like mud bricks. However, the newer stages of change in the village, consisting of the second, third and fourth stages of development (Fig. 8) started about 30 years ago and after the Iranian Revolution.

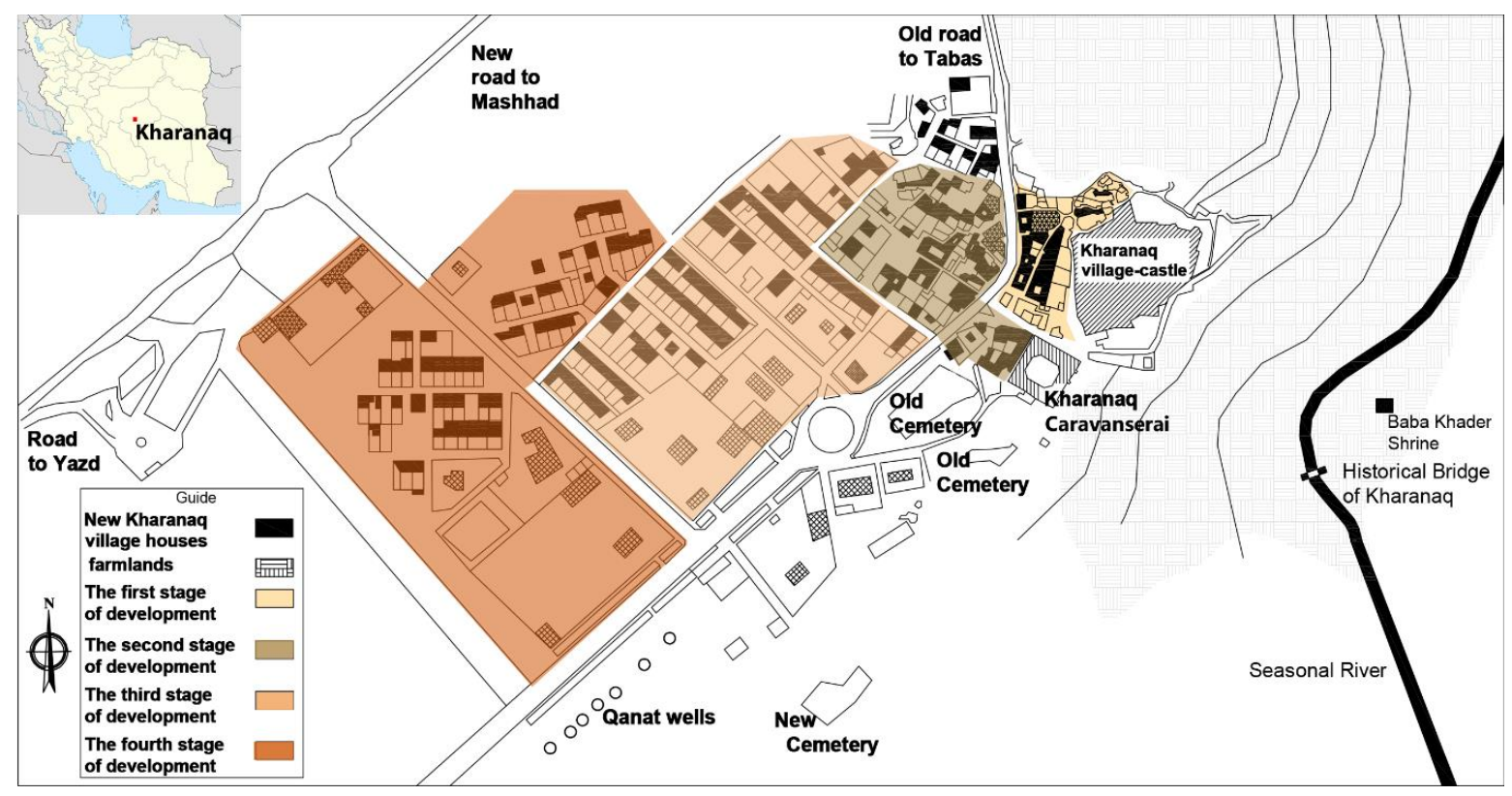

Fig. 8. The location of Kharanaq historical village on Iran's map and the site plan of the village and recent expansions of the modern housings. Sources: ICHHTO, Arman \& Hanachi, 2014, 71, and Islamic revolution housing foundation; redraw by the authors 
Due to the demolition of some residential houses inside the castle, population growth, and land scarcity, the inhabitants were given loans and support by the government to build their dwellings outside of the village-castle. These new houses were constructed in grid patterns of streets with very few signs of adaptation to the desert climate of Kharanaq and were very similar to the houses of modern cities (Arman \& Hanachi, 2014, 70-72). Given that these stages of the development in the village happened very fast due to the external stimuli, on the one hand, led the village-castle desolated and on the other hand, created a mismatch texture in its environment.

\section{SOCIAL INTERACTION AND GENDERED SPACES OF KHARANAQ VILLAGE-CASTLE}

The concepts of privacy and hospitality have had a great impact on home culture and housing formation of Iran. These cultural traditions come from a fundamental Islamic tradition, the control of social interaction between the sexes (khatib-chahidi, 1993, 115). This issue had an organizing role play of important patterns: pattern of privacy and pattern of hospitality. Two kinds of arrangements have been developed according to these patterns. One is developed to separate the private and reception areas of the dwelling, which is a pattern of privacy; another provided a special area for guests (Memarian and Brown, 1996, 45). These arrangements are the prevalent patterns of spatial organization in the traditional architecture of Iran. By analyzing the plans of village-castle's houses, some key assumptions were revealed about gendered roles and sexuality. We can observe the patterns of privacy and hospitality in the first and second typology of the village-castle's houses. However, in the third typology of the houses which is organized as a set of neighborhood units, it is hard to distinguish the private and reception areas of the houses. In the third typology of the houses which is occupied by more than one family that were usually relatives, the concept of privacy and gendered spaces differ from the prevailing traditional architecture of Iran. In these houses kitchen, which is a shared space between some families, represents the gendered roles and sexuality of these residential houses which are only allocated to women. Spatial organization of the houses interacts with the surrounding circumstances, preserves the social gendered norms and values, and reproduces the gendered structure that has originally contributed to its own shaping (Sadoughianzadeh, 2013,10). The analysis of the composition of the village-castle reveals that the house in the Kharanaq village-castle had a scale different from what we have in our homes today. In fact, the castle was a house where each of the inhabitants had one or several rooms. The scale of the house and the castle were the same, and the private and the public zones of a house in the village-castle had a different definition than the current one (Arman \& Hanachi, 2014, 71-72). It is also clear that the home, as a private concept was also prevalent within the castle and its inhabitants, but these divisions were in a more flexible way compared with other residential regions.

The placement of public buildings and spaces in the center of Kharanaq village-castle provided the opportunity of communication between the inhabitants. In addition to public spaces that people gathered together for particular purposes, there were other spaces in the village-castle that the inhabitants gathered together to do their daily works or have leisure times. One of these spaces was called Ghatilgah which had gendered divisions, and except for specific times, the opposite sex was not present in each of these spaces (Davarpanah, 2005, 23). Because of the unique composition and spatial organization of the castle, some gendered spaces have been created. One of these spaces in the village-castle is called Gharok, which is a place near the central mosque that women gathered together there, spinning, knitting, and talking to each other. It can be inferred from these spaces that how the specific "gendered relationships" are relevantly structured within these spaces.

\section{CONCLUSIONS}

Kharanaq village-castle and its vernacular and historical architecture is the result of thousands of years of human interaction and adaptation to the severe environment. Unfortunately, the new approaches have not taken into account the natural and historical potential of the Kharanaq village. The modern approaches of development wanted to impose a kind of mismatch livelihood to the environment while it is imperative to consider the valuable texture and framework of the historical monuments in further designs. The abandonment and vacant landing of the historic castle means 
a pause in the periodic repair of the components and the integrity of the historic castle. The gradual evacuation of the castle, which has been uninterruptedly continuous for a hundred years, has led to its severe destruction. Abandoning the social life of this village-castle and its natural and historical potentials precipitate the speed of its destruction. Developing vernacular tourism, creating vernacular residencies inside the village-castle for tourists, and encouraging the natives to preserve the historic castle by improving their economic situations are some of the means to revive the village castle of Kharanaq.

\section{BIBLIOGRAPHY}

Amiri, H., The report of record proposal in the country's national treasures list, Historic Castle of Kharanaq (In Persian). Yazd, Yazd Cultural Heritage and Tourism Organization, 2005.

Arman, F., \& Hanachi, P. Understanding the physical structure of Kharanaq village castle with an approach to the effects of behavioral patterns (In Persian). Journal of Iranian Architectural Studies, Issue 4, pp. 65- 86, 2014.

Davarpanah, A., Anthropological restoration of the social life of the Kharanaq castle (In Persian), Tehran, Center for International Studies and Collaboration of the Ministry of Science, Research and Technology, 2005.

Google Earth Pro, 2019.

Khatib-chahidi, J. Sexual Prohibitions, Space and Fictive Marriages in Shi ite Iran. In S. Ardener (ed) Women and Space: Ground Rules and Social Maps, revised edition Berg, Oxford, Oxford, pp. 112-134, 1993.

Memarian, GH. \& Brown, F., Patterns of Privacy and Hospitality in the Traditional Persian House. Paper presented at the fifth IASTE Conference: Identity, Tradition and built form: Working Papers Series Berkeley, PP. 42-82, 1996.

Sadoughianzadeh, M., Gender Structure and Spatial Organization: Iranian Traditional Spaces. SAGE Open, pp. 1-12, 2013.

Shahzadi, D., The detailed report of the Kharanaq Castle (In Persian). Yazd, Yazd Cultural Heritage Organization. PP. 1-12, 1995.

\section{AUTHOR'S NOTE}

Mojgan Aghaeimeybodi - Department of Architecture, Master of Iranian Architectural Studies, University of Tehran, Tehran, Iran. Corresponding Author.

Elham Andaroodi - Department of Architecture, Faculty Member, Associate Professor, University of Tehran, Tehran, Iran.

Contact | Kontakt: mozhgan.aghaei.meybodi@gmail.com; andaroodi@ut.ac.ir 